\title{
THE PROGRAM OF "NEW" AESTHETICS REGARDING THE EXPECTATIONS OF ARCHEOLOGISTS
}

\author{
PROGRAM „NOWEJ” ESTETYKI WOBEC OCZEKIWAŃ \\ ARCHEOLOGÓW
}

\author{
Danuta Minta-Tworzowska \\ orcid.org/0000-0003-3330-6025 \\ Wydział Archeologii, Uniwersytet im. A. Mickiewicza \\ ul. Uniwersytetu Poznańskiego 7, 61-614 Poznań \\ danminta@amu.edu.pl
}

\begin{abstract}
The article is devoted to considerations regarding the idea of ,new aesthetics” and its importance for archeology, especially prehistoric archeology. The current scientific reality as exceeding current paradigms and expanding research fields is diagnosed. This process also applies to the borders of art, which until recently seemed to be established, fixed and guaranteeing its clear separation from other spheres of life. The article shows aesthetics as noting this process and subject to change. This complicated current situation has created the idea of ,new aesthetics”, entering new areas that previously did not belong to art or aesthetics. Similarly, the methods of analyzing these phenomena do not have a predetermined status. This gives new opportunities, especially when you notice the manifestations of universal aesthetics. They also relate to prehistoric archeology, giving it the opportunity to participate in the discourse proposed by „new aesthetics.”
\end{abstract}

KEYWORDS: new aesthetics, art, archeology, archaeological discourse

The article refers to my earlier publication entitled: „Elementy 'nowej' estetyki a współczesna archeologia" and is its version significantly improved and going in a different direction than before (Minta-Tworzowska, 2018, p. 53-68). The new aesthetics and aestheticization have been under the interest of philosophers, art historians, sociologists and cultural anthropologists for many generations. There were archaeologists among them. The word itself comes from the Greek language and it is

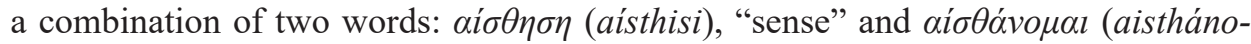
mai), "feeling". Already then, aesthetics was understood as knowledge of sensual cognition, of all perception (feeling, sensual experience). Therefore, the aesthetics was not only about the "beauty". A similar perception of aesthetics arose between 
the contemporary researchers who believe that each experience of any mental and emotional state may be a point of research of aesthetics, even if it is of interest to many fields. Researching of "aesthetic" experiences is conducted by the contemporary biology, neurology and experimental aesthetics. These disciplines ask questions if the aesthetic experience may be reduced to biological processes that occur in the human brain, and if so, which areas of the brain are activated during the experience of, for example, beauty. Being in accordance to brain activity during such experience, it is appropriate to believe that it is impossible to make such a far-reaching reduction. The "beauty" itself has to be defined, as well as "experiencing beauty", references the cultural values which are beyond the biological processes, including particular states of mind. It does not contradict the intuitive thesis that some of these experiences are "pleasant", evoked by particular objects, such as "pretty" things, works of art, thus we want to be surrounded by them more often than by the other things. Even the contemporary human being, brought up on the contemporary art and is familiarized with the "ugliness", is eager to visit the Old Masters' exhibitions.

\section{THE GOALS OF "NEW" AESTHETICS}

The "new" aesthetics has been created nowadays under the influence of the current events which may be defined as an overwhelming desire to emphasize that something new and original begins and the past ideas are outdated. The same atmosphere followed the raise of "New Archaeology" in the 1960s. It was similar to "new" philosophy and at last "new" aesthetics. It has been happening for at least two hundred years or even more.

The representative and founder of new aesthetics is Wolfgang Welsch (1997, 1998, 1999). He argues that aesthetization is the introduction of aesthetic elements into reality, giving it an "aesthetic polish" (Welsch, 1999, p. 17). In his opinion, reality becomes for us an aesthetic construct and next to superficial aesthetics (renewal, polish) there is a deep process in this (deep aesthetization). The world view is followed by "experiences", and this requires embellishing, decoration, from the workplaces to houses, flats (Welsch, 1999, p. 11).

The "new" aesthetics refers essentially to art, but it changes its character, and thus, the sense of the term "art". It wants to see it in "reality", not in the "ideality" which transfers to different aims than the previous ones - i.e. it is postulated to move away from constructing normative art models. The artistic phenomena are interpreted taking into account a broad social background and their social conditions. Therefore, social sciences are thought to be the ones that can deal with art. It is connected to the fact that knowledge about art itself becomes the "social art". The problem itself is complex, but the fact that a change in the research approach is forced, results in transformation in studies, including on prehistoric art.

In art, Krystyna Zamiara (1999) described this phenomenon as "transgressing ourselves". The borders which determined art were thought to be fixed, explicitly sep- 
arating it from other spheres of life. However, since they transgress, or they vanish, the same process touches aesthetics which is undergoing changes as well. It enters new areas that previously did not belong to art or aesthetics. The same situation happens to the methods of analysis of such issues. Many academic disciplines try to define the "close to life" art in a new way, and thus, they actually begin to deal with the processes of aesthetizing life. Nowadays, the idea of the art that is incorporated, "entangled" in life, $\mathrm{n}$ indistinguishable from the rest of reality is now being proclaimed, which makes this reality, as, for example, Odo Marquardt (2007) believes, a global "work of art" (Kostyrko, 1999, p. 55). For this thinker, art, and more precisely aestheticization of art should be a discipline-role model for the reality. It is a way of creating the world as aestheticizing of everydayness, not the opposite (Kostyrko, 1999, p. 56). In other words, the sense of art is not to embellish the world, but it is the world that draws on art as a model for its own creations.

What is the main "novelty" in the outlined approach? We can intuitively refer to the need of presenting the reality that is "prettier" and more enjoyable to the sense and perception - a tendency that has always accompanied a man. We may assume that people from the Paleolithic times wanted to improve their lives using various "tools", and one of them was aesthetics, which was the realization of their endeavors and suppositions. It was aesthetics that not only contributed to the transformation of shapeless matter into "nice", sometimes sophisticated things: tools, dishes, decorations, but also changed the environment of man and himself. Therefore, it seems that universal aestheticization is not just a feature of the present. Does this mean that history has come full circle? Is this a kind of return to the "beginning" when the aesthetics of the world was combined with it itself. We have made a huge effort to separate art and aesthetics from the rest of the world, paradoxically, to now re-introduce the aestheticisation of reality.

There is no doubt that there is a place in research for new aesthetics. Reflecting on these issues, it should be referred to the practice of contemporary artistic culture, as it did Teresa Kostyrko (1999). In other words, we should ask a question, how the contemporary culture is diagnosed by the new aesthetics? It should be noted that globalization is taking place on the one hand, and fragmentation on the other. There is no chance for a "new" contemporary Renaissance man. It does change the fact that the founder of new aesthetics Wolfgang Welsch (1999) thinks that a return to that idea is possible and valid. It would be a cause for the existence of the philosophy that is not divided into different disciplines. The contemporary division of philosophy and analytical philosophy omit the issues of human sensuality or the area of aesthetics. It comes from the fact that the aesthetics is thought to be the "philosophy of art" and it has dramatically narrowed the field of its theoretical inquiry and is not a successful project. Indeed, Welsch's idea is to return to the aesthetics as discipline of sensuality and about the aesthetic thinking at the same time. However, this process is complicated and results not only from the enthusiasm for artistic freedom and autonomy of art, but also from the consequences arising from its use, i.e. narrowing the audience who understand a given art and not another. As a result, aesthetics has become a field 
of public relations for art, promoting it as a product. Welsch believes that "aesthetics are useful idiots to the world of art," but on the other hand, artists themselves are increasingly "infected" by aesthetic theories. Does it mean that we should resign from it? No, aesthetics is the best tool for researching the process of aestheticization of reality that surrounds us, which is the "everydayness". Following Welsch further, we can agree that: "the next matrix of culture is hedonism" $(1999$, p. 14) which is a culture of pleasure. It connects the phenomenon with "superficial aesthetics", in which pleasure and entertainment reign.

In my opinion, festivals and festivities fit well in this sense of aesthetics, including archaeological festivals, cultural parks, in which the archaeological part is very important in order to revive and survive, as a suggestive encouragement. Aesthetics understood in this way has become a certain economic strategy in everyday life, in which the often refined aesthetic appearance is bought first, and the product itself comes second. Therefore, it is easy to replace an item with a new one just for the sake of a different look, not for the quality. The sales spiral and hunger for new products lead to the interchangeability of "existence" and "appearance", computer and software. The main object is software, not the computer itself, "semblance" not a being, copies (simulacra) and not the originals, aesthetics and not an object. Therefore, is it that the software becomes hardware? Aesthetics is now the currency of the society, the main value, not the product itself. When buying a new smartphone, we buy a lifestyle through it, some improved version of ourselves. Aesthetics from the role of the carrier turned into an essence. However, aesthetic processes are not only surface aesthetics, i.e. aestheticisation of the external appearance, but above all deep aesthetization, as Welsch calls it (1999, p. 15-17), intangible.

The contemporary world has a newer and new technologies to use each day, including digital ones. This applies to new manufacturing technologies that treat matter itself differently than before. New, complicated products are firstly tested, the 3D models are built, and using new technology allows for producing, not reconstructing, e.g., human bones, human face. Since it is possible to create something out of matter, out of plastic, aesthetics begins to play a leading role as the main "actor" of the simulation process. Matter, considered formless, resistant to changes, under its influence becomes a flexible and aesthetic material; appears to be susceptible to human ideas, having a non-material source. Not only are incredible things created today, but this has happened in all eras. It is easy to imagine that producing a hand axe, stone or metal axe was a miracle for a given society. Today it is similar, but it seems that they are produced easier. In the world of simulation, the original loses its importance and simulation is more "real" that the original itself, however, indeed it is understood as a "representation" of reality, not its "reproduction".

Another contemporary phenomenon is the construction of reality through or in media or in media. It is in media that the process of "unrealizing" from the world occurs. Computer games base on this. The images created by the media are selective, artificial, create a virtual world. Aesthetics participate in all of this, because they can be manipulated aesthetically. Certain documents, such as photography, which was 
attributed to the ability to map the world, have in fact become an unreliable document of reality. New technologies have made this happen. The world has become a virtual offer. Prehistoric past is also becoming such an offer. These new technologies have entered archeology, especially offering new ways to visualize archaeological data, based, among others on aerial photos or other non-invasive methods (e.g. Rączkowski).

In this simulation pressure, objects and life forms are stylized. We experience the stylization of body and soul and $t$ interpersonal contacts are increasingly stylized. Welsch describes this phenomenon as a new figure: homo aestheticus. Human being is characterized by auto-stylization (as it was described by Foucault, 1986, p. 18), or even narcism. This phenomenon can be also recognized as conformist, but depending on time, place and the spirit of epoch. The process of gaining of aesthetic values by the ethical norms is a result of the context of the reality that shapes the historical practices on one hand, and on the second, artistic practices. In the contemporary world, we notice an excess of aestheticization and aesthetizing, but this phenomenon has always been present to a greater or lesser extent. However, looking at the past through "glasses" of our culture, we can presume that we introduce the excess of aestheticization. Thus, we may assume that the world is subject to general aesteticization.

\section{SINCE THE WORLD IS SUBJECT TO GENERAL AESTHETICS, WHAT DOES “NEW" AESTHETICS OFFER IT?}

Before I try to answer to that question, I can risk a thesis that, on the basis of what has been written so far, a return to the modernist idea of art seems to be beneficial and safe. Then we would be based on traditional questions and traditional aesthetics. However, reality has gone a step too far and one cannot pretend that nothing happened. We are currently dealing with different aesthetics and a new artistic culture. We must therefore assume that aesthetics related to art is one of the varieties of aesthetization, but it is not the only one and does not follow one pattern. What different means aestheticization in the urban environment, which is different in the rural environment. Another thing is the aestheticisation of consciousness, which often takes the shape known to us from art - the shape of creativity. Aestheticisation refers once to beautiful things, once to stylization, and sometimes to virtualization (Welsch, 1999, p. 21). Here we have the ambiguity of the term aestheticization which has been visible from the times of Alexander Baumgarten, from 1735 (Baumgarten, 1750, after: Welsch, 1999, p. 21). According to him, aesthetics is a "discipline of sensual cognition". He perceived it as a field of the theory of knowledge, not only of art. Half a century later Georg Wilhelm Friedrich Hegel (1964-1967) recognized aesthetics as "the philosophy of the fine arts". Not much later Konrad Fiedler opposed that ideas and stated that "the aesthetics is not a discipline on art". More and more researchers that are against may be enumerated, thus, we can ask the question whether in such ambiguity and doubt there is any sense in using such an ambiguous term as aesthetization? 
According to Welsch (1999, p. 21-23), the solution may be found in Ludwig Wittgenstein (1972) and his idea of structure called "familiar similarity". Such "familiar similarity", as stated by W. Weslch, is aesthetics - there is no one thing that would be common to all aesthetic phenomena, but there are some which relate to each other. There are two meaning coming from that idea: the first one connected to aesthetic observation, and the second one linked to retrieving aesthetic content of the works of art and utility objects.

The first meaning is related to the fact that, in general, the term aesthetic refers to the sensual, although not every sensual impression is defined as aesthetic. It is more about sophisticated sensuality, sublimity and transience. The dual nature of sensuality relates to sensations and perception. For Kant (2004, H 30) "impressions [...] are directly related to the feeling of pleasure and unpleasantness" and he did not mean, however, the pleasure of the usual "sensual taste", but the higher pleasure of "reflective taste" (Kant, 2004, B 22), and therefore a semantic element. So the power of judgment as cognitive power refers to art and comes down to such feelings as pleasure or unpleasantness. It is somewhat "pre-rational" and its purposefulness can only be grasped in the field of art. Although Kant lacks a banal delight in art, the continuators of his thoughts were no longer free from this banality.

\section{“NEW" AESTHETICS AND OTHER UNDERSTANDINGS OF AESTHETICS}

Jurgen Habermas once proclaimed the fall of the ideology of modernism in favor of something happened "after", and which is difficult to clearly define, but this new era is called postmodernism. Modernism itself is often derived from the Renaissance, and it matured in enlightenment and positivism. The end of modernism is the end of "acting in the name of man" and the validity of the social slogan of the French Revolution: "freedom - equality - brotherhood", which actually realizes the Platonic ideals. In this context, we can ask what is future of aesthetics? Perception of proportions and forms is important to us and this is the first element of perception. The second is a specific theory through which we observe these forms. The distance assumed in the description of aesthetic features is a manifestation of theorizing. The third element of perception, defined to as phenomenalist, refers to the perception of the surface of things, the outside and the exterior. Therefore, the aesthetic term is associated with such meanings as apparent, phenomenal, superficial.

It is often emphasized that the aesthetic experience is subjective and is then dominated by a certain attitude. Sometimes the aesthetic concept reveals the perspective of "reconciliation" when the differences in the work are combined, covered, matched.

The most popular usage of the term aesthetic is synonymous with beautiful, and this combines all forms of sensuality, including reconciliation.

The second meaning is obtained by bringing to light the internal features of aesthetic objects. Often, the aesthetic term has a specific artistic meaning. This ap- 
plies, par exellence, to art that covers almost all elements of aesthetics: sensuality, transcending, viewing pleasure, harmonious forms and shapes, phenomenalism, holiness, beauty. Aesthetics also means competence in this area, a compliance with the theory of aesthetics. Sensitivity and aesthetic attitude are needed to bring out the features not seen by others. The last element is virtuality, which seeing reality in relation to aesthetic phenomena, combined in holistic systems. Virtuality intentionally makes the world light, transparent, and making it unreal acts in a biased, intentional manner.

Following Welsch, we may conclude that there is no single binding meaning for the word aesthetic. Although Welsch himself inclines towards the fact that the element of elevation could be such a basic sense of the term "aesthetic". He realizes that not everyone shares his view. He argues that other meanings may belong to the structure of one semantic element of "aesthetics". An example may be the hedonistic and theorizing element - they arise from other branches of meaning (the first from sensuality, the second from perception), but they are connected by a factor of elevation. In this way, you can move from one meaning to another, etc. Through this, we expand our concepts - in this case, aesthetics. This concept is not closed, it is flexible and stretchy.

Both Wittgenstein and Welsch pointed out that familiar similarities are a sufficient argument for the coherence and usefulness of such a concept as "aesthetic". This utility depends on the overlapping of different meanings, not on the continuity of one basic meaning. There must be connections between meanings, but they can represent different patterns. Therefore, it is not the linearity but multi-lineness of connections between meanings.

From the above considerations there are at least two approaches to aesthetization: one in which aesthetization is understood as having all aesthetic values by all phenomena. Objects are assigned with the attributes of "beauty" and treated as potential works of art. This approach is present today, in connection with art, but also with reality, although in a completely new reality. There is also a second understanding of aesthetization - it refers to the recognition of phenomena in accordance with aesthetics as a field of knowledge. This approach abstracts from art in considerations on aesthetics, ascribing it to reality, not just art. It gives us more possibilities.

\section{THE QUESTION ARISES: IS IT WORTH USING THE "NEW" AESTHETICS?}

Despite the outlined problems with defining aesthetics, there is a solution. One must recognize the semantic version with which we have to deal. If we want to analyze the objects and their presentations, we must also consciously choose to use this concept. Therefore, we must have knowledge about its applications, preferably all existing ones. It would be about applying full aesthetics, not partial, selective.

What does it mean? It is an objection to reduce nowadays aesthetics to research on art, that is, limiting aesthetics to art. This means sealing borders, defending access 
to everyday life, which Welsch calls "aesthetic-theoretical provincialism." Speaking only of aesthetics in the field of art, it is considered as if they were talking about the whole world of aesthetics. Here, too, there is a need for a proper understanding of art. Nevertheless, the new aesthetics clearly postulates opposition to the narrowing of aesthetics to the phenomena of art, and believes that this narrowing cannot be maintained, and the restriction can no longer be maintained.

The new aesthetics is to be a reflective aesthetics. The views of the 20th century were significantly influenced by Friedrich Nietzsche (1997), proclaiming that our reality designs have a completely aesthetic nature. Even the theory of science has permeated them, and analytical philosophy has taken over his view that we are like sailors who have to rebuild a ship on the high seas, listing its elements. Karl Popper (1977) or even Paul Feyerabend (1979) thought the same, arguing that the sciences do not behave essentially differently than the arts. Both work in harmony with a particular style, which depends on the way of thinking. This way of thinking determines what is true. Similarly, Richard Rorty was in favor of "socialized culture". Such a culture knows that our foundations are entirely constructed aesthetically and that they are completely cultural artifacts, which can be compared with other artifacts, but not with reality itself (constructivism). Today, the role of aesthetic elements in cognitive processes is clearly recognized. Certain solutions, even in the natural sciences, resulted from the aesthetic sense of the researcher, who allowed him to choose from many theoretical solutions to best explain a given situation (an example: James D. Watson [2001] and DNA structure). Sometimes, researchers even attribute scientific revolutions to changes in aesthetic canons, and not in ways of thinking (e.g., the big bang theory, the discovery of quarks, etc.).

We can agree with Welsch that in the last two hundred years aesthetics has overwhelmed the truth, knowledge and reality, so epistemological aesthetization has taken place. This phenomenon has been taking place since the times of Immanuel Kant to the self-reflection of modern life sciences. I refer directly to Welsch:

Since it has become clear that not only art, but also other forms of our activity, including cognition, have the character of production, aesthetic categories, such as appearance, changeability, diversity, groundlessness or foggy, they have become the basic categories of reality. (1999, p. 45)

Therefore, we treat reality as a created one, susceptible to modeling, to which we can introduce infinitely many changes. It becomes the subject of structural operations. We are witnessing a general aestheticisation of reality. The categories of this world of the type of permanence have been replaced by appearances, mobility, variety, and shakiness.

The concept of epistemological (reflective) aesthetics allows explaining contemporary phenomena and aesthetic processes: from technological to media everyday. However, can you withstand such pressure and aesthetic momentum? Even for Welsch, this is impossible. That is why he talks about aesthetics that is self-conscious, 
which idea is contained in the "blind spot culture". This is based on the thesis that perception of one means skipping something else. There is no vision without a blind spot. But through this we become more sensitive and attentive. This reflective aesthetics is to become a social tool. It is also about transferring aesthetic sensitivity to social problems. And what is becoming more and more obvious in art should be postulated in social life. We are dealing with "aesthetics beyond aesthetics".

The phenomenon of replacing moral norms with aesthetic does not worry such researchers as Welsch - on the contrary, we become tolerant, and accept social differences, and do not pass over them. However, in the face of momentous historical changes in societies, one should consider whether Marquardt was right, believing that the attitude to his own modernity is repeated from time to time and manifests itself in one of three attitudes: either the past is negated from the present point of view, the negation of the present in the name past or negating the present for the sake of the future. When diagnosing the present, some believe that it is a denial in the name of the future, because this is the program of postmodernism. However, after post-modernity comes modernity, of which Marquardt says that "has long been back", and this means "a return to bourgeois enlightenment." It also means a return to autonomous art and pluralization of the world. The historical sense is entering, which enables the coexistence of various aesthetics (including anesthetization) and the modern and postmodern one. There are cultural practices, including artistic ones, in our world that present the reality "unadorned", ugly, cruel, everyday (e.g. some exhibitions). They do not force new media and their pushy message. This means that even the introduction of a historical sense does not make our approaches to aestheticization fully understood. It may be necessary to repeat after Teresa Kostyrko (1999, p. 60), who in this matter refers to Welsch and Marquard and believes that aestheticization turns into anesthetization. There is now a phenomenon of aesthetic anesthesia, if everything is to be aesthetic. However, there are many more positives in the artistic culture trend, engaging in social issues from the perspective of theoretical sense.

In addition to the considerations, one may ask the question whether Jacques Rancière and his work "The Politics of Aesthetics: The Distribution of the Sensible" from 2000 may be included to the "new" aesthetics. In the work, the philosopher draws the relationship between, aesthetics and politics in the context of the proclaimed failure of modernism (Rancière, 2007a), pointing to a specific marriage of politics and art in today's world of exclusion. According to him, aesthetics alone is to be a node connecting art, thought and community (Doda-Wyszyńska, 2012). Rancière believes that discussions about the autonomy of art or its political subordination are pointless. Any "image" is not in the heart of art, but is a strictly ethical problem. It is not possible to establish a common communication platform for two separate discourses: e.g. between survivors of Shoah and those who have never experienced it. And only art understood as work is the highest form of discourse recognized as a dialogue, which from the ethical point of view is a "the distribution of the sensible" in a just way (Rancière, 2007a, p. 112). Artistic practices are therefore not unique among 
other practices; are an expression of work. The work itself is understood as the most characteristic activity of a person to whom he subordinates his life. Rancière's views bring us closer to the stairs leading towards archeological considerations in the spirit of aesthetics. Paradoxically, the category of work is operational, combining art with aesthetics.

\section{WHAT RESULTS FROM THE ABOVE CONSIDERATIONS FOR ARCHEOLOGY?}

The archaeologists talk about "art" as an element of prehistoric culture. They do this in two ways. According to the first, they see it in close association with other elements of culture (as part of e.g. magical culture). In the second case, they perceive a certain possibility of its separation, considering as its manifestation, e.g., paintings and rock, wall carvings, and the so-called prehistoric mobile art. In both views, they approach the idea of aestheticizing the world, which gives the opportunity to distance oneself from disputes regarding the legitimacy of talking about "art" in ancient times, shifting the weight of considerations to the processes of aestheticisation. Those who are wondering if this is "art", being aware that they are talking about a period of "preart era", they point out that art cannot be understood in the same way in relation to prehistory as it has been understood since the Renaissance. So, in essence, they take its different meanings or avoid the term "art". But this happens with every term, such as "economy", "technology" or "society", etc., with which we try to describe the prehistoric world. However, we have no choice; we use the current language and the way of thinking that goes with it.

From the "new" aesthetics program there are various consequences, also for archeology. Some are general and others more detailed and practical.

In a general sense, this new aesthetics means a return to understanding aesthetics as knowledge of sensuality and at the same time about aesthetic thinking. The new aesthetics are to be reflective, and so studies of aesthetics in archeology should be of this nature.

However, in terms of assumptions, aesthetics refers to the whole reality, and not only to the phenomena of art, thus we can try to analyze social prehistory and ancient everyday life in aesthetic categories. This significantly broadens the scope of archeology's interests. First of all, it also refers to "art" in its overall understanding without separating it from other areas of life. Reflection on what art is has a historical dimension and the same questions we ask today, we ask about the past. We look at the world through the 'glasses' of our culture; "We see" what is important to us, and we skip others. The problem of social conditions of art and aesthetics comes to the fore; is a signpost as a metonymy for contextual archeological studies. The importance of the context of widespread aesthetics in the modern world determines the of research questions in relation to the past, indicating the importance of the socio-cultural context of that time. 
"New" aesthetics gives a different view on the method, i.e., it introduces the assumption that the usefulness of the aesthetic concept depends on the overlapping of different meanings, not necessarily in a linear way, and even contradicts this. The method of analysis that is useful for archeology is the analysis of various types of related aesthetics (superficial, deep) through observation and extraction of aesthetic content. We can take a step forward and combine this idea in archeology with the socalled new materiality, especially with the most current view, i.e., the concept of entanglement. In my opinion, only "getting back to things" or "defending things" - paraphrasing Bjørnar Olsen (2010), the introduction of "actor-network theory" by Bruno Latour (1996), gave the opportunity to combine perspectives previously impossible to combine in one theory or methodology. In turn, the so-called entanglement theory combines human and non-human, science and humanities on one "screen", on one film, in their connections, entanglements, which was previously unacceptable (due to different logic of scientific reasoning, argumentation, etc.).

Thus, in archeology, there can be a place for reflective aesthetics in a agentive role, i.e., aesthetics understood as a social tool. Nowadays, this role tends to limit such views that everything that is aesthetic, illusory, simulated is important. Limiting the recognition of the past as a product that should be sold - archeology "sells" nostalgia, as Zbigniew Kobyliński (2005) once wrote. It allows you to commune directly with "pretty" things or their copies, and offers all this as an area of extraordinary experience. Festivals, virtual museums, the idea of time travel, etc., are perfectly suited to this. However, this is not just the agentive role in studies of aesthetics - it is more about showing how different elements of culture and non-culture could be seen on one "screen" by prehistoric people. Thanks to this, the whole was much more expressive, clear than its individual elements such as everyday life, rituals, separated and separated places, such as cemeteries, "art galleries", etc.

It is the idea of "entanglement" that gives a different view of the world. On the one hand, this is our thinking arising in the present, but on the other hand, we cannot resist the need to say something sensible about the distant past, about people in ancient times. That is why we put our thinking on the past, but it must be done in a reflective and not automatic way.

\section{INSTEAD OF SUMMARY}

My final reflection will be less optimistic than the entire current text. Why? I have previously recognized that blurring the "borders" of languages, sciences and art is generally a positive phenomenon. But it also has some anxieties. In place of research approaches or schools, appear the so-called methodological turns, as exceeding a given methodology. "New" aesthetics was also to be such a turn. These turns are multiplying rapidly, which means that the term "return" seems to have worn out, lost its meaning as something momentous, important. It is as comparing the current turns to a dance return, not a U-turn (the latter understood as diametrical). Another narrative 
appears, often having the features of personal experience, evoked by a moment, some reading, fusing with "torments" of knowledge in the style of "young Werther". The nature of theory is also changing - it becomes a kind of dramatization of narrative, more subject to the rules of art than science. The understanding of theory as ordering and classifying the world to some extent disappears. Also in this is a confusion of our knowledge with ignorance, which is also manifested in moving concepts of uncertain significance, the appearance of completely new ones. It is these "entanglements" that shape us and our knowledge. They result from experiences, emotions, repetitions, coincidences, to which we attach special importance. We succumb to the charm of the research field, which houses overlapping possible worlds, as a kind of topographic palimpsest. We see the prehistoric world as a palimpsest, but our knowledge and ignorance acquires the character of a palimpsest through a kind of confusion, giving the drama of our "overall" narrative, thanks to which it becomes more expressive, which is not usually indicated by the analysis of individual elements. What is more, it is not known why this happens, that the state of the whole system is better defined than its individual parts.

For the sake of order I will add that Ian Hodder (e.g. 2016) is the propagator of the idea of entanglement as a method of analysis and interpretation in archeology, and the "balance between human and non-human world" is promoted most strongly by the "symmetrical archaeologists", advocates of "getting back to things" (Olsen, Shanks, Webmoore, Whitmore, 2012). There are also works marked by deep emotions, almost personal experiences (e.g. Nekros, Ewa Domańska) and many others. Of course, I am not saying that their basic theses arose solely in the atmosphere of "new" aesthetics, but they certainly resulted from blurring borders, showing the complications of the world, and a kind of confusion of our knowledge and ignorance. And in this sense, the importance of "new" aesthetics should be emphasized as co-creating a climate for greater openness and changes in the understanding of art and aesthetics. Many of its elements can be found in the collective work published in 2018 entitled „Estetyka w archeologii. Obrazowanie w pradziejach i w starożytności” (Minta-Tworzowska, 2018).

The above considerations also indicate that the "turns" are no longer as momentous as before, and they are happening almost in parallel with other turns, although the "new" aesthetics cannot be denied the features of originality.

\section{BIBLIOGRAFIA}

Baumgarten, A. 1970 [1750] Aestetica, Frankfurt nad Odra. Reprint: Hildesheim: Olms.

Doda-Wyszyńska, A.

2012 Inwazja ikonoklastów. Filozofia przedstawienia Jacques'a Rancière'a. Poznań: Wydawnictwo UAM.

Feyerabend, P.

1979 Jak być dobrym empirysta. Warszawa: PWN. 
Foucault, M.

1986 Der Gebrauch der Luste. Frankfurt am Main: Suhrkamp.

Hegel, G. W. F.

1964-1967 Wyktady z estetyki. Trans. J. Grabowski, A. Landman. Warszawa: PWN.

Hodder, I.

2016 Studies in human-thing entanglement. Published on-line at: academia.edu, researchgate, and ian-hodder.com

Kant, I.

2001 Krytyka czystego rozumu. Trans. R. Ingarden. Warszawa: Antyk.

2004 Krytyka władzy sądzenia. Trans. J. Gałecki. Warszawa: Antyk.

Kostyrko, T.

1999 W kwestii estetyzacji i anestetyzacji oraz praktyki współczesnej kultury artystycznej. In

K. Zamiara, M. Golka (eds), Sztuka i estetyzacja (p. 53-64). Poznań: Humaniora.

Latour, B.

1996 On actor-network theory. A few clarifications plus more than a few complications. Soziale Welt, 47, 369-381.

Marquardt, O.

2007 Aesthetica und Anaesthetica. Rozważania filozoficzne. Warszawa: Oficyna Naukowa.

Minta-Tworzowska, D.

2018 Elementy „nowej” estetyki a współczesna archeologia. In D. Minta-Tworzowska (ed.), Estetyka $w$ archeologii. Obrazowanie $w$ pradziejach $i$ w starożytności. Warszawa: Wydawnictwo Polskiej Akademii Nauk - Muzeum Archeologiczne w Gdańsku.

Nietzsche, F.

1997 Z genealogii moralności. Trans. G. Sowiński. Kraków: Znak.

Popper, K.

1977

Logika odkrycia naukowego. Trans. U. Niklas. Warszawa: Aletheia.

Olsen, B.

2010 In Defense of Things. Archaeology and the Ontology of Objects. Lanham, MD: AltaMira Press.

Olsen, B. Shanks, M., Webmoor, T., Witmore, Ch.

2012 Archaeology The Discipline of Things. Berkeley: University of California Press.

Rancière, $\mathrm{J}$.

2007a Estetyka jako polityka. Trans. P. Mościcki, J. Kutyła. Warszawa: Wydawnictwo Krytyki Politycznej.

2007b Dzielenie postrzegalnego. Estetyka i polityka. Trans. M. Kropiwnicki, J. Sowa. Kraków: Korporacja Ha! art.

Schiller, F.

1972 Listy o estetycznym wychowaniu człowieka i inne rozprawy. Trans. I. Krońska, J. Prokopiuk. Warszawa: Czytelnik.

Watson, J. D.

2001 A Passion for DNA: Genes, Genomem and Society. Oxford: Oxford University Press.

Welsch, W.

1997

Estetyka i anestetyka. Trans. M. Łukaszewicz. In R. Nycz (ed.), Postmodernizm. Kraków: Wydawnictwo Baran i Suszczyński.

1998 Estetyka poza estetyką. O znaczeniu estetyki w czasach współczesnych i o nowej formie dyscypliny. Trans. K. Zamiara. In A. Seidler-Janiszewska (ed.), Problemy ponowoczesnej pluralizacji kultury. Wokół koncepcji Wolfganga Welscha (p. 81-103). Poznań: Humaniora.

1999 Procesy estetyzacji. Zjawiska, rozróżnienia, perspektywy. In K. Zamiara, M. Golka (eds), Sztuka i estetyzacja (p. 11-52). Poznań: Humaniora. 
Wittgenstein, L.

1972 Philosophische Untersuchungen: Dociekania filozoficzne. Trans. B. Wolniewicz. Warszawa: PWN.

Zamiara, K.

1999 Epistemologiczny kontekst psychologii partycypacji kulturowej. In K. Zamiara, M. Golka (eds), Sztuka i estetyzacja. Studia teoretyczne (p. 137-150). Poznań: Humaniora.

\title{
THE PROGRAM OF “NEW” AESTHETICS REGARDING THE EXPECTATIONS OF ARCHEOLOGISTS
}

\author{
Streszczenie
}

Zasadnicze pytanie dotyczy tego, co wynika dla archeologii z założeń „,nowej” estetyki. W znaczeniu ogólnym stanowi ona powrót do rozumienia estetyki jako nauki o zmysłowości i jednocześnie o myśleniu estetycznym. Istotne jest również to, że nowa estetyka ma być nauką refleksyjną. Podobnie studia nad estetyzacją $\mathrm{w}$ archeologii powinny mieć taki charakter.

Kolejny aspekt oczekiwań archeologów mieści się w obszarze założeń. Pierwsze z nich mówi, że estetyka odnosi się do rzeczywistości, a nie tylko do zjawisk sztuki, dlatego można analizować w kategoriach estetycznych społeczną codzienność pradziejową i starożytną. Poszerza to znacznie zakres zainteresowań estetyki na gruncie archeologii. Drugie założenie wskazuje na to, że estetyka odnosi się do również do sztuki, w całościowym jej rozumieniu, bez oddzielania od innych dziedzin życia. Pytania, czym jest sztuka, mają wymiar historyczny i zadajemy je z naszej, a więc współczesnej perspektywy. Dotyczy ten problem przeszłości pradziejowej czy wczesnodziejowej, na którą patrzmy przez „okulary” naszej kultury. Trzecie założenie odnosi się do uwarunkowań społecznych sztuki. W archeologii wychodzi ono na pierwszy plan, stanowiąc pewien drogowskaz dla archeologicznych studiów kontekstowych. I ostatnie, czwarte założenie, które eksponuje wagę kontekstu powszechnej estetyzacji we współczesnym świecie i waży na zadawaniu pytań badawczych w odniesieniu do przeszłości, wskazuje na znaczenie właśnie ówczesnego kontekstu społeczno-kulturowego.

Założenia „nowej” estetyki przekładają się również na metody badań. Wychodzi się w niej od tezy, że użyteczność pojęcia „estetyczny” zależy od nakładania się różnych znaczeń, niekoniecznie w sposób liniowy, i należy do rozpoznawania/nadawania znaczeń dostosować metodę analizy. Jedna z proponowanych metod, która jest przydatna dla archeologii, to analiza różnych rodzajów estetyzacji „spokrewnionych” ze sobą (powierzchownej, głębokiej) przez „obserwacje” i „wydobywanie treści estetycznych".

Obecnie formułowane są nowe pytania wobec rzeczywistości, którą się zajmujemy. Są związane z nową teorią społeczną, z nową materialnością i sprawczością rzeczy. Dlatego ujmuje się refleksyjną estetykę w roli sprawczej jako narzędzie społeczne, idące niekiedy w kierunku ograniczania poglądów współczesnego świata na nią samą (iluzoryczność, symulacja itp.), ograniczania ujmowania przeszłości jako produktu, który należy sprzedać - bo archeologia „sprzedaje” nostalgię (Kobyliński, 2005), a przeszłość staje się „przemysłem” (Pawleta, 2011). W tę rolę doskonale wpisują się festyny, wirtualne muzea, idea „time travel”, w której realizacji odgrywa ona rolę priorytetową, jako płaszczyzna doznań, przeżyć.

Z perspektywy nowej estetyki archeologia zyskuje bardzo wiele; nie musi się thumaczyć, czy twórczość ludzi pradziejowych wolno ujmować w kategoriach sztuki i estetyki, bowiem uprawnione jest przenoszenie wartości estetycznych na całą rzeczywistość niejako od początku zaistnienia 
człowieka. Uprawnione są również studia nad malarstwem jaskiniowym paleolitu w kategoriach „sztuki” jako istotnego elementu ówczesnego świata i jego rozumienia estetyczności. Podobnie jest w pracach dotyczących rytów skandynawskich lub wyrafinowanej biżuterii, ozdób, różnych form naczyń, narzędzi, a nawet konstrukcji domów, osad, grobów itp., czyli wszelkich działań wytwórczych społeczności pradziejowych. To współczesność wybiera język narracji, który dotyczy - w przypadku archeologii - odległej przeszłości, i nie jesteśmy w stanie tego zmienić, jako zależni od aktualnych kompetencji kulturowych. Dlatego z pewną pokorą należy przyjąć, że poznajemy przeszłość w teraźniejszości i nie ma innej perspektywy poznawczej, w skład której wchodzi nasza zastana wiedza i nasze oczekiwania wobec przeszłości. To one kształtują pytania badawcze i sposoby odpowiedzi na nie. Co podkreślałam wcześniej, w tej wizji przeszłości nie chodzi tylko o przeszłość, ale o nas samych, jak kształtujemy obrazy na jej temat. „Nowa” estetyka włącza więc w ten dyskurs archeologię jako pełnoprawną dziedzinę. 